Колоїз Ж. В.

доктор філологічних наук, професор, ДВНЗ «Криворізький національний університет»

\title{
МОВОПРОСТІР ТА СВІТОГЛЯДНІ ПРІОРИТЕТИ ПОЕТИЧНОЇ ТВОРЧОСТІ ВОЛОДИМИРА КАЛАШНИКА
}

У статті йдеться про світоглядні пріоритети поетичної творчості Володимира Калашника, проаналізовано ї̈ стилістичні ресурси, акиентовано передусім на звукових і тавтологічних повторах (алітерація, асонанс, кільце, симплока), виявлено стилістичні прийоми та засоби, що слугують для увиразнення поетичних текстів, розширюють структуру асоціативно-образних рядів.

Ключові слова: поетичний текст, часова категорія, буття, стилістичні ресурси.

В статье исследуются приоритеты мировоззрения поэтического творчества Владимира Калашника, анализируются стилистические ресурсы его поэзии, акцентируется внимание прежде всего на звуковых и тавтологических повторах (аллитерация, ассонанс, кольцо, симплока), выясняются стилистические приемы и средства, которые служат выразительности поэтических текстов, расширяют структуру ассочииативно-образных рядов.

Ключевые слова: поэтический текст, временная категория, бытие, стилистические ресурсы.

Speech goes in the article about world view priorities of poetic work of Volodymyr Kalashnyk, she is analysed stylistic resources, it is accented foremost on voice and tautology repetitions alliteration, assonance, ring, symphloke), stylistic devices and facilities, that serve for underlining of poetic texts, extend the structure of associativevivid rows, are educed.

Key words: poetic text, sentinel category, existence, stylistic resources.

Володимир Калашник - знаний в Україні мовознавець і громадський діяч, автор не лише наукових і науково-методичних розвідок, а й художніх творів, що увійшли до поетичних збірок «Осінній дивоцвіт» (2000), «Бентежне надвечір'я» (2004), «Біла зоря» (2006), «Незгасимі світи» (2010), «Осоння осені» (2012). Визначальними рисами його поезій є лірико-філософське сприй- 
мання світу, осягнення минулого, пройденого, пережитого, урівноваженість художньо-образного мислення. Його поетичні рядки вирізняються простотою, здатною породжувати найрізноманітніші асоціації. У них - і світла радість любові, любові до жінки, батька-матері, до рідного полтавського краю й України загалом, і щира сповідь перед Богом та людьми за власні вчинки (і не тільки!), і біль ранніх утрат, і тривоги сьогодення... Утім, про особливості своїх поетичних творів досвідчений стиліст, який неодноразово вражав читача своїми стилістичними відкриттями [Калашник 2011], говорить так: Комусь мій стиль - банальність $і$ не більме, Перейдені, забуті рубежі. Сучасний критик не сприймає віршів, В яких круті відсутні віражі. Звичайна річ: стара самітня мати, мандрівка в юність і дитинства світ, І вічний слід до батьківської хати, Що нас зове на сповідь і на звіт. Вже ні до чого давній кодекс честі, Коханиями розкрадено любов, Поезій місие заступають тексти, Що рвуться на паркан, а не в альбом [Калашник 2012 : 176].

Одним із найсуттєвіших здобутків Володимира Калашника $є$ вироблення власного мовно-поетичного стилю, де кожен текст - це «прагнення передати свою духовну настроєність, водночас зберігаючи осібність, власні інтонації на густо заселеній царині» (В. Боровий), адже читаєш його вірші і «ловиш себе на думиі, щзо маєщ справу зі спогадами душі, бо душею, а не розумом вони написані» (А. Стожук). На цьому наголошує сам автор: За Слово не сховатися: у Слові Душа живе - хоч грішна, хоч свята. Усі земні діяння пам'ята Народжена устами рідна мова. 3 буденним поряд є у Слові Боже - Те, щуо з Любові, Віри, Чистоти. Безсмертя Слово дарувати може, Але до нього треба дорости [Калашник 2012 : 175]. Калашникове поетичне слово, як і життя, починається з любові, а Любов дарує $i$ слова від Бога, в яких злилися дума та чуття, - 3 небес святих Поезї дорога. Усе земне любов'ю огорта Поетове і Боже віме слово. У ньому і глибінь, і висота, I невмирущість маминої мови [Калашник 2012 : 141]. Тому, очевидно, «не випадково дослідник мови поетичних текстів став відомим поетом, творчість якого сьогодні є об'єктом літературознавчого і лінгвістичного аналізу» [Калашник 2012 : 6]. 
Мета нашої наукової розвідки полягає в тому, аби на матеріалі вибраної лірики [Калашник 2012] дослідити мовопростір та виявити світоглядні пріоритети Володимира Калашника-письменника.

Поетична творчість Володимира Калашника репрезентує широкий спектр ідей, образів, ситуацій, зображально-виражальних засобів. Його ліричні роздуми про смисл людського буття вражають щирістю, чутливістю, правдивістю, його «душа не тільки відкрита для любові, болю, співпереживання, а й готова довіритися духовно близьким людям» [Калашник 2012 : 3]: Уже з гори, а не нагору: Тому повільно, не спішу. І не боюся поговору, Що віршем молодо гріму. Чуттями повню кожне слово, Мов шлю до юності листи. Я прагну до гори основи У слові душу донести [Калашник 2012 : 91]. У поетичному слові втілені як найпотужніші й найгомінкіші «стрімкі весняні потоки внутрішніх людських переживань», так і «щемка бентега у швидкоплинні миті осоння осені», оте бентежне надвечір'я, коли людина, так би мовити, намагається підбити підсумки зробленого і пережитого: Осоння осені. Останній пломінь літа Вгортає душу в тихий супокій. Погожі дні. Іще не в 'януть квіти. Відходу кроки - скрадливі й легкі. У ніч пливуть осінні міражі Бентежні сни снувати до світанку. І в стомленій закоханій душі Нуртують сиві мрії наостанку. П'янке жадання стрічі - не прощань! Несуть солодкі сонячні хвилини. У бабиного літа павутини Впліта осоння осені печаль. Час дивоцвіту, і бентег, і розстані, Незгасної зорі в осонні осені [Калашник 2012 : 5]. Весна, літо, осінь, зима є наскрізними образами-символами в поетичному доробку митця, слугують своєрідним життєвим календарем: Співаю гімн весні $i$ ліму, Хоч осінь зиму вже стріча. Несу у світ я правди світло На вістрі слова - не меча [Калашник 2012 : 83]; Спочатку літо, потім осінь Втекли від мене. Йде зима... У тому світі безголосім Життя лим видимість сама. У тім холоднім безгомінні Все завмирас чи вмира. Життсвим радощам на зміну Приходять присуди: «Пора!» Десь тут кінчається початок минулих сподівань $і$ втіх. А поряд мчать з гори санчата I в них дитячий спомин-сміх [Калашник 2012 : 
137]. Кожна пора року уособлює певний етап життя людини: весна це юність, пора кохання, пізнання чогось нового, незвіданого (Весь день дощить. Журою світ наповнений. Вдивляюся у сиву пелену. Це, власне, і не дош, а невеселі спомини Про те, чого ніколи не верну. Минули дні, де все було по-іншому: Був світлий і щзасливий дощопад, Життєва путь тоді здавалась вічною, весна манила розкішшю принад... I стільки там було пісень неспіваних! Душа любов'ю й мріями цзвіла. А провесінь із думами осінніми Ще зовсім неможливою була [Калашник 2012 : 103]); літо - це період соціальної зрілості, що передбачає зрілість мислення, сформованість світогляду, життєвої позиції, економічну самостійність, політичну грамотність, моральну відповідальність, професійну підготовленість і т. ін. (І знову літо відшуміло. Моє багатство - стільки літ! Веселкам сонячним на зміну прийшов осінній дивоцвіт. Гаї у розкоші сумирній Лягли вінком на втому нив. Вже журавлів журливий ирій $B$ далекі мандри поманив. Стаю під корогви Покрови, Приймаю щедрий Божий дар. Дні золотисто-пурпурові Ще повні пристрасті й жадань! [Калашник 2012 : 8]); осінь - це період похилого віку, коли людина отримує життєвий досвід, мудрість, починає розуміти справжню сутність речей та їх реальну цінність (Прийшла пора щемливої бентеги 3 вечірньою зорею вдалині. Все більше сподівань на обереги, Що долею даровані мені. Та не шукаю тихого причалу: Тривога рання душу підійма. Жагучим словом осінь зустрічаю. А на порозі молода зима [Калашник 2012 : 62]); зима - це період старості, коли знижується працездатність, погіршується стан здоров'я і т. ін., людина починає думати про вічний спокій (Tu, пізня осене, сумна: вістуєш зиму - білий саван. Ворон різкими голосами Нагадуєш про карму нам - Невідворотний ріменещь... I справді: вчора - лиш отець, Сьогодні-дід... і на причалі. Вже й радість в образі печалі. I так тривожно пада сніг... та посміхається вві сні Моє кумедне онучатко. Все починається спочатку.. [Калашник 2012 : 22]). Такі часові поняття по-народному прості й прозорі. Весна асоціюється 3 радістю, осінь - із журбою, вони постійно перебувають у контрастному 
протиставленні. Щоправда, у поетичній творчості Володимира Калашника переважають так звані «осінні мотиви»: Радіє осінь - йде iï пора. Туман прощань вгортає наймиліше. I сад не цввіт, а зрілий плід колише. Пливе назустріч радості жура [Калашник 2012 : 18]; Не багатий осені ужинок, та стихає врешті маята. Тихопад замріяних сніжинок Супокоєм душу огорта [Калашник 2012 : 76]; Вже відспівала осінь падолиста Сумну свою мелодію прощань. Вогні зірниць холодних зайнялися. Спімать морози навзамін дощам. I літо, й осінь щзедро всім платили. Нащьо природі гандж $і$ бариші? Пес одиноко щулиться під тином. I щемно холодіє на душі [Калашник 2012 : 130]; Ці білосніжні айстри восени - Немов літа мої помолоділі. Між різнобарвних посестер вони Несуть иявітіння заметілі. Щемка печаль із осені біліє, В небесну даль готуючи земне. Як ия краса зів'яне $i$ зітліє, Безмірним вічним холодом війне [Калашник 2012 : 131]; Пора щцедрот, прощчальна, перелітна. Плодами цุвіту мліє все живе. На павутинках бабиного літа Моя душа до обрію пливе [Калашник 2012 : 78]; В осінню пору дощ сльозами крапле. Душа дрімає, вгорнута в печаль. Не знаю, де життя поставить крапку I де знайду останній свій причал. Та прийде час, коли в годину пізню Я свій земний життєпис допишу. Його фіналом стане (вірю!) пісня, В якій $і$ серцее, й душу залишу. Поставлю в ній три крапки, замість крапки. Нехай все те, щуо я не доказав, осінній день дощинками прокрапле I запечалить осені сльоза [Калашник 2012 : 77].

Розмірковування поета про людське буття виходить за межі аналізованих часових категорій, пов'язується передусім 3 таким поняттям, як життя: Життя людське - краплина в морі, лиш мить, щзо плине у віки. Допоки світять маяки, біліє світ, ясніють зорі... Жага жадань довіч незмірна. Жадає космосу доріг Моє бентежне надвечір'я На поклик білої зорі [Калашник 2012 : 94]; Допоки ще земні не стихли кроки, Доповнюю життя можливий слід. I пробую вернути ненароком Життєву стрілку з заходу на схід [Калашник 2012 : 99]. Згідно з художньо-образною концепцією митця, смисл життя - у самому житті, у кожній неповторній його 
миті, яку треба цінувати, насолоджуватися, бо прожитому вде ніколи не буде вороття: Прекрасна мить мина, у вічність кане. Що віджило, не знає вороття. Літа пливуть, лягають пелюстками На дивоплід із іменем - Життя. Не поспішай до плоду визрівання. Іди на гору - не спіши з гори. I певно вір, допоки Бог тримає, В довічність пелюсткової пори [Калашник 2012 : 98].

Людське життя, переконує митець, з одного боку, то рух, 3 іншого, - короткий сон земний, який, можливо, не мине безслідно, а перейде у вічність, воно тримається на вірі і надії, узгоджується 3 морально-етичними нормами, закоріненими в Божих Заповідях, а відтак - за кожен свій крок і кожне своє діяння людина звітуватиме перед Богом: Не тільки совість - Бог усіх карає. Не вбереже від суду херувим. Анкету вже заповнено до краю. Немає місия записам новим. Було всього: $і$ старти, і бар'єри. Стелився шлях асфальт і спориші. Червона біографія кар'єри I справжня біографія душі. Життя - то рух, коли воно не тління, Дотичні в русі навіть полюси. Подбай, щуоб не покинуло сумління, Й на фініш чисту душу донеси [Калашник 2012 : 93].

Життя - анкета, життя - календар, життя - повість... Попри різні асоціативні ряди безсумнівним залишається те, що книга життя - велика таїна - знаходиться за сімома замками, вона написана про нас, але до нас, і змінити що-небудь людина не в силі: Свого життя перегортаю повість I там знаходжу кілька сторінок, Написаних не прямо, а натомість, Бо замість руху лиш непевний крок. Звитяжні дні трудів без нагороди, тверда хода і другове плече. За миті слабодухості - обходи - Докором сонще західне пече. Але на все земне веління Боже: На поступ $і$ падіння, сміх $i$ плач. Сюжет життя змінити вже не може Ні автор, ні герой, ані глядач [Калашник 2012 : 124]; О скільки літ зозулі накували! Розщедривсь час на мій зозулин лік. Підніжжя гір, вершини перевалів, I старт, і фініш, а між ними - пік. Життева книга писана трудами, Сувій набутків скромних розгорта. Стежки й дороги обхідні і прямо - Усе вмістили пройдені літа. Питаю в Долі, чи 
була щуаслива. Гортаю том життя календаря. Там - чесний труд і праці щедра нива. А над усім - незраджена зоря [Калашник 2012 : 187].

Повсякчас простежується думка: кожна людина повинна чітко усвідомлювати відчуття своєї минущості, відчуття того, що не вічна вона тут, на землі, бо є смертна. Однак, зауважимо, у поетичному доробку письменника зовсім відсутні такі лексеми, як смерть, помирати; ці поняття маніфестуються перифрастичними зворотами, як-от: Відплаче чайка при дорозі I ві́чай мій, і твій відча́й. Зоставить нас на перевозі Дорога дорогих стрічань. А далі-послуги Харона: Ніщо? Чи може, знову даль У невідомість за поромом? Не розлучатися б бодай! [Калашник 2012 : 108]; Зосталось небагато перевалів, тому в обхід, все рідше - навпрямки. Молюсь, щуоб шлях $і$ далі осявали Твойх очей незгасні маяки. I ще прошу свою Любов-Месію: Стели дороги віри і безмеж, даруй одвічне диво воскресіння I за останнім перевалом тежс [Калашник 2012 : 10]; Батьки мої вже відійили в світи. Ïх душі - у космічному просторі. 3 дитинства зір мій ваблять тихі зорі-між них я прагну маму віднайти [Калашник 2012 : 106]; I знов «курли» щемливо-журавлине До серия лине кличем висоти. То час земний відлічує хвилини На старті у незвідані світи. Ми теж колись сумними журавлями Розтанемо в захмарній висоті. Онук печально на прощання гляне, Слова молитви шепчучи свя$m i . .$. [Калашник $2012: 135]$ тощо.

Перехід у незвідані світи - закономірний, невідворотний етап, що є продовженням земного життя, від нього залежить, яким саме буде цей крок: Земне жнття, скінчившись, не згасає, А пломенем здіймається в світи. Покликане у вічність небесами, Воно сія в безмежжі висоти. Тому нас вабить у космічні далі Безвиході утрат наперекір. I погляд наш усупереч печалі 3 надією мандрує поміж зір [Калашник 2012 : 140]; Усе коротмають солодкі сни. Все більше місия для жури й розпуки. Сни забирають дочки і сини, Сум відганяють щебетом онуки. < ..> Коли ж мій шлях земний, -короткий сон 
цеей, - Скінчиться й дзвін прощально відгуде, Я вірю, щуо моє життєве сонце Не в прірву, а у вічність упаде [Калашник 2012 : 101].

Однією з основних об'єктивних форм існування матерії, яка виявляється в тривалості буття, є час. Тому цілком закономірно, що письменник досить активно послуговується відповідною матеріальною формою вираження як у прямому, так і в переносному значенні: На березі часу усі розчаровані: Одні - щуо зупинка, а хтось - щзо кінецьь. Контрольна ревізія душ і сердець, Прощуання 3 омани віниями й коронами. А далі-безчасся чи час благовісний. Те буде без нас, ніби ми й не жили... Дарма. Дуиу й серце лишити б у nісні, Щоб сонще намадкам світило з імли [Калашник 2012 : 125]; Спливає час ще швидше, ніж вода. Одна лиш мить - $і$ листя опада...[Калашник 2012 : 39]; Все виняткове й випадкове У наших споминах живе. На щзастя знайдена підкова - Удачі дзеркало криве. А справжнє з іншого свічада Погляне пильно (прийде час!), Не феєрверком і парадом - Усім життям освітить нас [Калашник 2012 : 81] тощо. Часові уявлення поета тісно пов'язані з просторовими: подорожі у просторі супроводжуються і змінами темпоральних ознак: Крізь скло, сумне і непрозоре, Збираю видиво імли. Веселі осені узори Вже потьмяніли, відбули. Повз час $і$ проминулі села Прямує потяг до зими. Снується дума невесела: так відбуваємо $і$ ми [Калашник 2012 : 128]. Часопростір подекуди маніфестується подіями особистого чи суспільно-політичного життя: Самує хата у селі колишньому. Віконниці торкаються землі. Чиїсь надї й клопоти полишено У цүім безлюднім кинутім селі. Не споришем поpic, а лободою Нічийний двір. Криниия - без води. Невже судилось під Полин-звіздою Дощам змивати пам'яті сліди?.. Неподалік. За ближнім косогором, Дорога мчить байдужих у світи. Самує хата. Совість не говорить. Немає часу пам'ять берегти...[Калашник 2012 : 104]; Перегорни листки календаря I зазирни в майбутнє - не минуле, Щоб учорашні нам не повернули Той час, коли кривавилась зоря. Нехай не стане в круговерті літ Ні канонад, ні пострілів «Ав- 
рори», А серце з серием на зорі говорить, Коли благословляється на світ [Калашник 2012 : 88] тощо.

Мовностилістичний малюнок поетичних творів Володимира Калашника увиразнюється не лише за допомогою розширення структури асоціативно-образних рядів, а й внаслідок використання найрізноманітніших стилістичних ресурсів. Для аналізованої поетичної творчості є характерним гармонійний принцип звукової організації віршів, грунтований на поєднанні і взаємодії контактних і дистантних повторів. Ті чи ті образи набувають яскравості передусім завдяки засобам алітерації та асонансу: $У$ полі знову половіє жито,

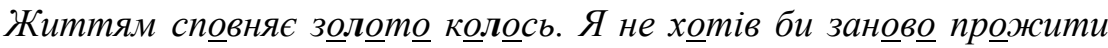
Все те, щ⿻ вже прожити довелось. Як і раніш, коли б Госодня воля, Приймав би в серие радощі й жалі, Мов нагороду ніс утомму 3 поля I силу брав від матері-землі [Калашник 2012 : 75] (звукова картина лагідного літа постає завдяки ритмічній повторюваності плавного за тембром приголосного л; благозвучності віршованої мови, посиленню їі музикальності сприяє асонанс, або повторення

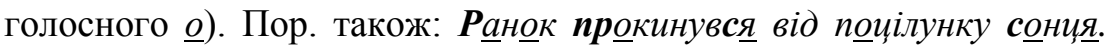

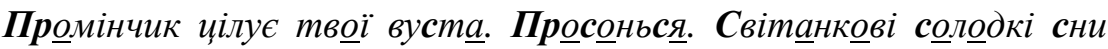

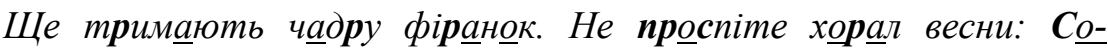
лов 'їниться раннок... [Калашник 2012 : 82] (алітерація p, $\boldsymbol{n p}, \boldsymbol{c}$; асо-

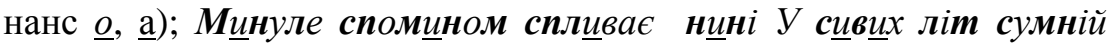
самотині. Прекрасна митть, зупинена в світлині, Враз повертає у квітучі дні [Калашник 2012 : 165] (алітерація $\boldsymbol{\mu}, \boldsymbol{H}, \boldsymbol{л}, \boldsymbol{p}, \boldsymbol{\boldsymbol { c }}, \boldsymbol{c}, \boldsymbol{n}, \boldsymbol{m}$; асонанс $\underline{u}$ ). Унаслідок подібних звукових повторів, які доволі часто накладаються, взаємодіють, посилюються звукообразні характеристики тексту, створюється відповідний емоційний настрій.

Майстерно послуговується письменник не лише звуковим, але й різними лексичними (тавтологічними) повторами - повторами тих самих, спільнокореневих або близьких за значенням (подібних за звучанням) слів: Жага пекуча, невситима. Кипить усе єство моє. А спеки спекатись несила: Усюди сонце дістає. Спекотно гріта й перегріта, Природа підганяє нас, Застеріга на схилі 
літа Про рукавиці на запас. Якби ж то рукавищі тільки Могли спасіння принести, Вернути шал земної втіхи Нам на калинові мости [Калашник 2012 : 117]; Надійко, не відходь за ту межу, звідкіль не буде видно Украӥни. Не піддавайсь спокусі віражу, Що забирає рани і руїни. <... В Вкраӥну та сім'ю не сироти - Лугань благає $і$ Дніпро широкий. Не загасай, світи на всі світи, надіє із родини доброоких [Калашник 2012 : 85] (вірш присвячено Надії Світличній); Знаю: не мину твого крайнеба, Як дорога дійде до межі. А душа всякчас летить до тебе В пошуках рятунку від олжі. Чом же так не сталось, як гадали? Ходять поруч злидні і круті. Залишилась доля у кайданах, I тьмяніють ниви золоті. Найстрункімі маємо тополі, Небеса черкаємо крильми... Григоре, нам горе $i$ на волі, Бо забули, як були людьми [Калашник 2012 : 50] (вірш присвячено Григорові Тютюннику). Подекуди такий прийом є наскрізним, тавтологія присутня в кожному рядку одного поетичного твору: Прилетіли літа на обжинки схололого літа, Стерновищами жита розіслали моє жстття. Мало їх у цвіму, більш оббитого грозами цвіту. Час вартує ворота - нема літам вороття. А літа - мов брати, тільки б извіт поопалий зібрати, І повернеться сила, вони ж бо з оцього села. Ген біліють хати, закликають до отчої хати. Перевесла в'яжу й на кормі не лишаю весла. За шинки не віддам свої скромні житейські обжинки. Ще межа не прожита, щее вруняться в полі жита. Хочу впасти у житі, неземне буття переживши. А на заході літа нові пломеніють літа...[ККалашник 2012 : 41].

Лірика Володимира Калашника ілюструє зразки такої стилістичної фігури, яку кваліфікують як кільце, або обрамлення, де наявне здебільшого повторення початку і кінця вірша: Яка зелена тиша навкруги! Довкіл п'янке липневе різнобарв'я. I поплавка стрімкого завмирання На плесі, щзо в хустині з окуги. Тут плине час привільно, без снаги Стежиною від хати на помості. Дрімає серие у солодкій млості. Яка зелена тиша навкруги! [Калашник 2012 : 73]; Не повертаються із вирію Мого дитинства жсравлі. Вже не одну верству відміряно Від стежки отчої землі. - Курли, 
курли! - I не вертаються. Десь загубилися в імлі. Далекі мрійнї̈ літа мої Взяли на крила журавлі. У серизі все, щзо стало спомином. Моя стежина край села. Дощами бита, вмита росами, - Навкіл зросли нові жита! - Вона в мені із неба просинню, Маленька ниточка життя... Як і колись, тривожусь мрією, Не відриваюсь від гіллі. Та не вертаються із вирію Мого дитинства жсуравлі [Калашник 2012 : 35]. Доволі часто різні тавтологічні повтори взаємо-

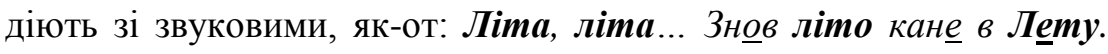
Осоння осені - остання мить тепла... Алㄹ вㄹна, довічний дар поету, Із літом за межу не відбула. Поетів спів - веселккою над

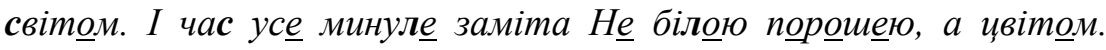
Осоння осені.... Любов... Ліма, літа...[Калашник 2012 : 61].

Як і кільце, композиційної стрункості надає поетичним текстам і симплока, або сплетіння, коли кожна строфа починається i закінчується відповідним повтором (звуковим, лексичним чи синтаксичним): Дивний світ. Ти його до скону Не пізнаєш і не збагнеш. У природи свої закони. І свос беззаконня тежс. // Диво й зваба - життя основа. Все шукаємо щастя: де ж? У життя є свої закони. І свос беззаконня теж. // Дивне серие. Його ніколи Не примусиш триматись меж. У кохання свої закони. І свос беззаконня тежс [Калашник 2012 : 9].

Лірична оповідь автора забезпечується не лише різними повторами, а й умілим використанням градації, гіперболи, інверсії, паралелізму, парцеляції, персоніфікації [УМ 2000] і т. ін.: Я хотів би по швидше втекти від розлуки, А втікаю від зустрічі в збурений світ. Під перестук коліс і гудків перегуки Утікаю від тебе, від себе, від літ. Забираю у спомин пороги й причали, неповторні близькі і далекі краї, Де гостинно і радо мене зустрічали I прощали блукання й утечі мої. Синій птах поманив не коритися прозі. Журавлями у небо надї знялись. Щоб літа наздогнали в дорозі й тривозі На останній зупинці. Не зараз. Колись [Калашник 2012 : 67]. Тут і епітети (збурений, неповторні), й антитеза (близькі і далекі), i градація (Утікаю від тебе, від себе, від літ), й однорідні сурядні 
ряди (гостинно і радо; пороги й причали), й інверсія (гудків перегуки; блукання й утечі мої), і фразеологізм (синій птах - символ щастя, ідеалу; те, що втілює для кого-небудь найзаповітніші мрії, прагнення), і парцеляція (Щоб літа наздогнали в дорозі й тривозі На останній зупинці. Не зараз. Колись), і персоніфікація (Журавлями у небо надії знялись).

Поетично олюднюючи довколишній світ, Володимир Калашник створює свіжі оригінальні метафори: Пелюстками літа облітають із квіту весни [Калашник 2012 : 14]; В едем безхмар'я увірвалась злива Й покрила нас потоками дощу [Калашник 2012 : 109]; Усе лікує споминів бальзам. Щаслива мить долає вічність болю [Калашник 2012 : 15]; Медом пахне земля. Сонце повне снаги. Мліє день у світлиці гарячого літа [Калашник 2012 : 40]; Ці ручаӥзимові сльози Чи сльози радощів весни? Духмяним золотом мімози Вони примчали з далини. Знов березневі талі води - Кохання юні голоси - Співають про жіночу вроду I сяйво чистої краси [Калашник 2012 : 56]; 3 сяйного дня заходжу в ніч, чаруюсь зорями ясними. I ось знаходжу (дивна річ!) Свою любов отам, між ними, Де красень-місяць угорі Пливе по ночі до світання I повні зорі на зорі Дрімають, зморені коханням [Калашник 2012 : 68]. Метафоричність поетичного світогляду письменника нерідко породжує додаткові асоціації, а взаємодія різних стилістичних ресурсів забезпечує потужні виражально-зображальні можливості, звичайні загальновживані слова набувають високого ліричного звучання і великої естетичної сили, як-от: Дві хмарки збіглися в одну, Десь буркнув грім сердито, Похмуре небо після сну Згадало, щуо не вмите; Пробігся вітер поміж трав, Пригладив жито в полі, А потім хвацько обійняв За стан струнку тополю... Тополя гнеться на горбі, Листочками тріпоче, неначе вирватись з обійм Вона від вітру хоче. I раптом - вітер відлетів: Тополя стрепенулась, В промінні міднозолотім До сония посміхнулась. Так радісно і любо їи, - Що двом весняні грози?!... А з голубих листочків-вій На землю впали сльози [Калашник 2012 : 32]. Зауважимо: у проілюстрованому тексті наявні 
деякі спільні моменти (такий собі образ вітру- коханця) 3 поезією Василя Симоненка «Суперники» («Вітер пісню співав стоголосо..»).

Слід, очевидно, наголосити й на тому, що автор вдало й успішно послуговується алюзією як на усну народну творчість, так i на літературні художні тексти своїх однодумців: До України повернусь... А я й не розлучався з нею. Живу коханою землею 3 найменням отчим гордим - Русь. Вона одна, колосозерна, В святій молитві Кобзаря. Довічних див степи, озера... I чиста вранішня зоря. Хай інших манять далі прерій, Готова розкіш-машкара. Я твій навіки, роде древній, - Нема жс бо другого Дніпра [Калашник 2012 : 21] (алюзія на твір Тараса Шевченка «І мертвим, і живим, і ненародженим...»); Прокинулось, всіхнулось, задзюрчало - I знову брость у зав'язь вибуха. Отак би й нам почати все спочатку, щзоб вогник у cmeny не затухав <...> Весні - иьвісти, а лебедю ячати. Прощцання біль у серичі не вщуха. Нема кінця, а є лише початок. I вогник у cmeny не затуха [Калашник 2012 : 47] (алюзія на повість Григора Тютюнника «Вогник далеко в степу»; вірш є присвятою письменнику-земляку); Десь плине річка невеличка Поміж піщаних берегів. А тут підземна електричка Несе нас долі навздогін. $С$ в інших і життя, $і$ мрї, Над ними -сонце без ножа. А наше світить, та не гріє, Бо вже перейдена межа. Синіють десь волошки в полі-Краплинки неба на землі. А ми між хмар шукаєм долі На перебитому крилі [Калашник 2012 : 126] (алюзія на поему Івана Драча «Ніж у сонці»; вірш є присвятою письменникові); $O$, де та мить, щзо ми ї̈ згубили?.. Летять літа, несуть нас до землі. На мілині гадаєм про глибини: В руках синиці, в небі жсрравлі [Калашник 2012 : 34] (алюзія на прислів’я Краще синичя в руиі, ніж журавель у небі) тощо.

Значну роль у поетичному доробку письменника відіграють ключові слова-символи - калина, явір, соловей, журавель, зозуля, зоря тощо, які доволі часто виступають у його мовопросторі своєрідними фольклорними маркерами, а деякі тексти стилізовані під українські народні пісні, окремі з них покладені на музику. Части- 
на мовних фрагментів набула статусу афоризмів (пор.: $У$ всякої гори своє підніжжя: Вершини починаються з землі; Дозрілий плід нового прагне иявіту; Мелодії кохання - найніжніші. Без музики любові не бува; Душа без слова - гіnc, а не скульптура). Щоправда обмежений обсяг статті не дає нам змоги більш детально зупинитися на всіх стилістичних ресурсах, майстерно застосованих автором у представленому поетичному доробку, де переважають мінорні настрої: Почуття - мов гербарію квіти поснулі... Замість радісних зустрічей щемні розстання. То літа, щз мені накували зозулі, так поспішно й нещадно минулими стали. Думка-мрія відтак переходить у спомин. Долітують літа в сонщеліта розповні. I залишиться людям - можливо, на подив - Мій літопис життя 3 палімпсестом любові [Калашник 2012 : 164].

Володимир Калашник майстерно модифікував невичерпні художні багатства рідної мови, уміло розширив обрії поетичного мовопростору, збагатив українську поезію новими темами. У ній і незабутні враження від творчого спілкування 3 колегамимовознавцями, письменниками, і засудження дій та вчинків псевдовождів і псевдоеліти; тут і про суспільство загалом, і про людину $з$ іiі внутрішньою сутністю, безмежним духовним світом, і про сенс людського буття. Його поетичні тексти - це лірикофілософське осмислення минулого, пройденого, пережитого крізь призму морально-етичних норм, закорінених у Божих Заповідях. Вони набувають особливого мелодійного звучання завдяки вмілому використанню найрізноманітніших стилістичних ресурсів, що, взаємодіючи, створюють довершені образи, які впливають на свідомість, розум, почуття.

\section{БІБЛІОГРАФІЯ}

Калашник 2011 - Калашник В. С. Людина та образ у світі мови : вибрані статті /

Володимир Калашник. - Х. : ХНУ ім. В. Н. Каразіна, 2011. - 368 с.

Калашник 2012 - Калашник В. С. Осоння осені : Вибрана лірика /

Володимир Калашник. - Х. : Майдан, 2012. - 192 с.

УМ 2000 - Українська мова : Енциклопедія / редкол. В. М. Русанівський,

О. О. Тараненко (співголови), М. П. Зяблюк та ін. - К. : Укр. енциклопедія

ім. М. П. Бажана, 2000. - 752 с.

Стаття надійшла 2 вересня 2013 р.

УДК 82.09 (420) 